\title{
HUMAN DIGNITY AND THE CONSTRUCTION OF IDENTITY IN THE OLD TESTAMENT
}

Louis Jonker

Old Testament

Stellenbosch University

\begin{abstract}
The status of Israel changed dramatically as a result of the Babylonian exile and its aftermath during the Persian era. Whereas the self-understanding of the people was closely linked to the Davidic monarchy during the pre-exilic time, the post-exilic community had to face the reality of their provincial existence under Persian imperial rule. The sociopolitical and socio-cultural environment changed dramatically because of these events, resulting in renewed processes of identity negotiation in Israel. We witness different attempts at verbalizing these processes in the biblical writings. The impact of the Persian imperial context on the self-understanding of the community in Jerusalem will be investigated with special reference to the Books of Chronicles. In these books - different to from e.g. Ezra-Nehemiah - a tendency towards inclusivism can be detected in the process of identity negotiation. This paper will show how this tendency relates to the qualified tolerance that was characteristic of the Persian (Achaemenid) era.
\end{abstract}

Key Words: Human Rights, Persian History, Persian Period Biblical Literature, Chronicles

\section{Introduction}

The preamble of the Universal Declaration of Human Rights ${ }^{1}$ adopted by the General Assembly of the United Nations almost 61 years ago, states, inter alia,

Whereas recognition of the inherent dignity and of the equal and inalienable rights of all members of the human family is the foundation of freedom, justice and peace in the world...

Whereas the peoples of the United Nations have in the Charter reaffirmed their faith in fundamental human rights, in the dignity and worth of the human person and in the equal rights of men and women and have determined to promote social progress and better standards of life in larger freedom..

It then continues with the formulation of thirty articles in which the inalienable rights of human beings and nations are set out. This document which sees the inherent dignity of all human beings as the foundation stone of all these rights has been influential in our world since its promulgation. For example, the South African Constitution of 1996, in chapter 2, includes a Bill of Rights which takes its cue from the Universal Declaration. In article 10 of the SA Constitution ${ }^{2}$ it is stated: Everyone has inherent dignity and the right to have their dignity respected and protected.

\footnotetext{
Taken from http://www.un.org/en/documents/udhr/ (accessed 20 October 2009).

Taken from http://www.info.gov.za/documents/constitution/1996/96cons2.htm\#10 (accessed 20 October 2009).
} 
Again, the strong relationship between the inherent dignity of human beings and the rights they may claim forms the basis of this chapter of our constitution.

These documents, of course, have a history. They were not formulated on one peaceful day as a noble expression of human wisdom. They are rather the products of some of the darkest experiences that humankind has witnessed. The Universal Declaration was formulated after World War Two, after a large part of the world was destroyed by war which was the result of power abuse and destructive ideologies. The South African Bill of Rights was included in the constitution of a new democratic South Africa after a dark period of apartheid ideology and politics. These expressions are imaginations of an alternative reality after the self-destructive potential of humanity was witnessed.

An interesting artefact in the United Nations Headquarters in New York reminds us, however, of other histories with which the notion of human rights is also connected. A copy of the so-called Cyrus cylinder, an Akkadian cuneiform inscription dating back to 539 $\mathrm{BCE}$, is exhibited in one of the foyers of the UN Headquarters. This copy was handed to the then UN general-secretary, Sithu U Thant, on October 14, 1971 by Aschraf Pahlewi as a present from Iran. The UN general-secretary, in his address of acceptance, indicated that this copy was a historical present, since it could be considered to be an ancient declaration of human rights in which the Persian emperor, Cyrus, expressed his commitment to peace among nations and his respect for other civilizations.

Did this occasion at the UN Headquarters present a significant link between ancient history and the modern declaration? An answer to this question remains controversial, since Aschraf Pahlewi who presented the copy of the Cyrus cylinder to the UN was the twin sister of the then Shah of Iran. The backdrop of this gesture to the UN was a great festivity in Iran at the same time in October 1971 when the Shah invited the world to celebrate together with him 2500 years of Persian kingship. It is very clear that the Shah, who had solid backing from the United States, wanted to portray his own leadership in continuity with the emperors of the past, particularly the great King Cyrus who was presented as a king of peace and tolerance.

Although these occasions at the UN and in Iran were already controversial back in the 1970's, they were again remembered in the reaction to the acceptance speech of Shirin Ebadi, the first Iranian and Muslim woman to receive the Nobel Peace Prize in 2003. She was awarded the Nobel Peace Prize for her many efforts to promote a human rights culture in Iran and the Muslim World that protects the dignity of women, children, the poor and the suffering. In her speech, titled 'In the name of the God of Creation and Wisdom', she based her actions on the Universal Declaration of Human Rights. But then she continued with some interesting remarks: ${ }^{3}$

I am an Iranian. A descendent of Cyrus the Great. The very emperor who proclaimed at the pinnacle of power 2500 years ago that '... he would not reign over the people if they did not wish it.' And [he] promised not to force any person to change his religion and faith and guaranteed freedom for all. The Charter of Cyrus the Great is one of the most important documents that should be studied in the history of human rights.

The debate about whether the Shah of Iran and his twin sister, as well as the Nobel Peace Prize Laureate of 2003, made legitimate use of their Persian history and ancient documents to support their views on human dignity and human rights, still continues to the present day. Even Der Spiegel, an influential news magazine in Germany, published a most

Taken from http://nobelprize.org/nobel_prizes/peace/laureates/2003/ebadi-lecture-e.html (accessed 20 October 2009). 
provocative article under the title 'Der falsche Friedensfürst' (the false emperor of peace) during $2008^{4}$ in which all these actions were condemned to be ideological tricks. Also the well-known National Geographic published in the same year ${ }^{5}$ a feature article carrying the title "Persia: Ancient Soul of Iran. A glorious past inspires a conflicted nation."

Despite the very obvious ideological nature of the abovementioned gestures and expressions, these examples illustrate well the clear relationship between tradition, history and authoritative sources in a given culture on the one hand, and the views that representatives of that culture would hold on the issue of human dignity and human rights, on the other hand. It emphasizes that discussions on human dignity and human rights always involve a hermeneutical element.

This is certainly not different in South Africa. It has already been indicated above that the Bill of Rights in our constitution should always be discussed against the background of the violation of human rights during the sad history of Apartheid. The South African case is also not different since South Africans rely heavily on their authoritative traditions, also religious traditions, in their appropriation of a culture of human dignity. In the Christian community, the Bible often serves as source from which the convictions about human dignity are motivated - a fact that is confirmed by this very workshop on 'Biblical Perspectives on Human Dignity'. It is within this context that I would like to make a contribution to our present discussions.

I will focus on perspectives that we may gain from specifically some of the Old Testament literature that had its origin during the Persian era, that is, in the period in which the Persian Empire exercised considerable influence over Judah and Jerusalem. The hypothesis that I depart from in my contribution is namely that the self-understanding and identity negotiation processes reflected in these biblical texts are indications of how the Jewish community situated themselves in the historical environment of Persian imperial rule. $^{6}$ I do not pretend that my observations of the identity negotiation processes reflected in these books will clear once and for all whether the Persian Empire since Cyrus really was such a tolerant society that respected human dignity - the application of these terms to the ancient societies would in any case be anachronistic. However, these observations could at least sensitize us to different ways in which the socio-political changes of those days were appropriated in the communities in Jerusalem.

First of all we will have to look at the international scene of the post-exilic phase in Judah's history. This will involve an exploration of the alleged tolerance introduced by Cyrus, the Persian Emperor. Thereafter, a selection of Old Testament literature will be studied. I will not offer full blown discussions of each of these pieces of literature, but will rather endeavour to answer how this literature engaged with the wider imperial context of the time. This exercise will hopefully help us to identify how the community in (mainly) Jerusalem engaged with their local and international context.

See Der Spiegel 28/2008, 126-128.

See National Geographic August 2008.

Although I do not repeat my theoretical points of departure here, my use of the social-psychological notion of 'textual identities' in other publications stands in the background here. See particulary LC Jonker, "Reforming history: The hermeneutical significance of the books of Chronicles," Vetus Testamentum 57/1 (2007), 21-44; Idem, "Textual identities in the Books of Chronicles: The case of Jehoram's history," in Community Identity in Judean Historiography: Biblical and Comparative Perspectives (eds. GN Knoppers and K Ristau; Winona Lake, IN: Eisenbrauns, 2009), 197-217; Idem, "David's Officials according to the Chronicler (1 Chr. 23-27): A Reflection of Second Temple Self-categorization?" in Historiography and Identity (Re)Formulation in Second Temple Historiographical Literature (ed. LC Jonker; New York: T\&T Clark, 2010), forthcoming. 


\section{The Historical Context: Persia and Yehud}

We start our discussion with the very ancient document referred to above, namely the Cyrus Cylinder. This document, which was found in the ruins of the ancient city of Babylon in 1850, was not written by Cyrus or any other Persian, but was rather authored by priests of the Babylonian god, Marduk, in the city of Babylon after Cyrus of Persia took command of this capital in 539 BCE. In this Akkadian text it is indicated that the god Marduk was dissatisfied with the Babylonian king, Nabonidus, because of his numerous crimes, his desecration of the temples of the gods, and the forced labour he imposed on the population. Marduk then looked around and identified Cyrus, the Persian, to become ruler over Babylon - with the god's blessings.

In a first person section of the document Cyrus then provides a self-description of his rule. I quote from a translation: ${ }^{7}$

Cyrus' titles

20 I am Cyrus, king of the world, great king, mighty king, king of Babylon, king of Sumer and Akkad, king of the four quarters, 21 the son of Cambyses, great king, king of Anšan, grandson of Cyrus, great king, king of Anšan, descendant of Teispes, great king, king of Anšan, 22 of an eternal line of kingship, whose rule Bêl and Nabu love, whose kingship they desire for their hearts' pleasure. When I entered Babylon in a peaceful manner,

\section{The prince of peace}

23 I took up my lordly abode in the royal palace amidst rejoicing and happiness. Marduk, the great lord, established as his fate for me a magnanimous heart of one who loves Babylon, and I daily attended to his worship. 24 My vast army marched into Babylon in peace; I did not permit anyone to frighten the people of [Sumer] and Akkad. 25 I sought the welfare of the city of Babylon and all its sacred centers. As for the citizens of Babylon, [x x x upon wh]om he [i.e., Nabonidus] imposed a corvée which was not the gods' wish and not befitting them, 26 I relieved their wariness and freed them from their service. Marduk, the great lord, rejoiced over [my good] deeds. $27 \mathrm{He}$ sent gracious blessing upon me, Cyrus, the king who worships him, and upon Cambyses, the son who is [my] offspring, [and up]on all my army,

\section{Religious measures}

28 and in peace, before him, we mov[ed] around in friendship. [By his] exalted [word], all the kings who sit upon thrones 29 throughout the world, from the Upper Sea to the Lower Sea, who live in the dis[tricts far-off], the kings of the West, who dwell in tents, all of them, 30 brought their heavy tribute before me and in Babylon they kissed my feet. From [Babylon] to Aššur and (from) Susa, 31 Agade, Ešnunna, Zamban, Me-Turnu, Der, as far as the region of Gutium, the sacred centers on the other side of the Tigris, whose sanctuaries had been abandoned for a long time, 32 I returned the images of the gods, who had resided there [i.e., in Babylon], to their places and I let them dwell in eternal abodes. I gathered all their inhabitants and returned to them their dwellings. 33 In addition, at the command of Marduk, the great lord, I settled in their habitations, in pleasing abodes, the gods of Sumer and Akkad, whom Nabonidus, to the anger of the lord of the gods, had brought into Babylon.

Mordechai Cogan's translation, in WH Hallo and KL Younger, The Context of Scripture vol. II, Monumental Inscriptions from the Biblical World (Leiden: Brill, 2000) - online version http://www.livius.org/ctcz/cyrus_I/cyrus_cylinder2.html (accessed on 20 October 2009). 
Cyrus' prayer

34 May all the gods whom I settled in their sacred centers ask daily 35 of Bêl and Nâbu that my days be long and may they intercede for my welfare. May they say to Marduk, my lord: 'As for Cyrus, the king who reveres you, and Cambyses, his son, ...' 36 The people of Babylon blessed my kingship, and I settled all the lands in peaceful abodes.

The interpretation of this document is, as we have already seen, controversial. Scholars of Persian history ${ }^{8}$ are more or less in agreement that this text, which was written in the Mesopotamian genre of a royal building inscription, was rather the result of the innerBabylonian dissatisfaction with their ruler and an explanation why the Persians under Cyrus's leadership were allowed in $539 \mathrm{BCE}$ to enter the gates of Babylon without any resistance. And we know that from there Cyrus conquered the Middle East to form one of the largest Empires ever known. The Cyrus cylinder was rather a Babylonian instrument to legitimize the royal rule of the Persian emperor, Cyrus, over Babylon.

How should the very peaceful and tolerant character of Cyrus which is reflected in the document then be evaluated? This question becomes pertinent for our discussion since some biblical texts, such as Deutero-Isaiah and Chronicles, also portray Cyrus in a very positive light. Deutero-Isaiah even calls him the messiah, and Chronicles sees his liberation of the Israelite exiles as a fulfilment of the prophecy of Jeremiah!

Josef Wiesehöfer, a historian specializing in ancient Persian history, provides a good description of what is often referred to as the pax Achaemenidica, an ideology of peace and tolerance promulgated by the Persian rulers.

In one of his most recent publications ${ }^{9}$ Wiesehöfer comments as follows about the conditions under Persian rule (also called the Achaemenid Empire after the family name of many of the Persian rulers): "Although basically 'composite' in character, the Achaemenid Empire was not simply an ensemble of countries and peoples or a 'confederation' of political entities with only loose ties among them; institutional variety does not exclude political unity. On the contrary, ... the Achaemenids were able to make cultural diversity serve the needs of imperial unity... To their subjects they applied a clear and simple standard: loyalty ... was rewarded, disloyalty severely punished... In general, the Persians fostered good relations with organizations and elites in subjugated territories as a means of pacification and of lowering the costs of running the empire. Respect for the cults of subjugated peoples, the use of local elites as administrators of subjugated territories, and the fostering of an imperial ideology that encouraged a view of mutual benefit all created favorable preconditions for enhanced economic and political performance."

Wiesehöfer mentions the following important trait of the Persian kingship: "(A)s his kingship is owed to the favor of Auramazda, ${ }^{11}$ the king is obliged to protect the god's good creation... Order, not chaos, peace, not tension, and good conduct of the subjects and royal generosity, not disloyalty and kingly misbehavior, dominate the inscriptions and the imagery of the royal residences." 12 This royal ideology is then closely linked to what

8 See e.g. P Briant, From Cyrus to Alexander. A History of the Persian Empire (Winona Lake, IN: Eisenbrauns, 2002), 41; A Kuhrt, The Persian Empire: A Corpus of Sources of the Achaemenid Period (London: Routledge, 2007), 70-72.

9 J Wiesehöfer, 'The Achaemenid Empire', in The Dynamics of Ancient Empires (eds. I Morris and W Scheidel; Oxford: Oxford University Press, 2009), 66-98.

$10 \quad$ Ibid, 86.

11 Ibid, 94 indicates that "( $\mathrm{t})$ he Persian kings ... did not try to create and enforce a divine hierarchy: local gods were never seen as subordinate to Auramazda."

12 Ibid, 88-89. 
Wiesehöfer calls a 'Persian national identity.' He describes it as follows: “(A)lthough something akin to a 'Persian national identity' can be noticed in the royal inscriptions, imperial ideology at the same time aimed at integrating the elites of the provinces within an empire-wide ruling class culture, even at integrating subjugated peoples into a kind of imperial 'symbolic universe.' No inhabitant of the empire was forced to choose between an 'imperial' and a 'local' identity... However, (they were) not granted the possibility of rejecting this second identity by rebelling against Persian rule."13

The imperial ideology described here by Wiesehöfer is often referred to in the literature as the so-called Pax Achaemenidica. ${ }^{14}$ It was an ideology that stressed the reciprocity of royal care and loyalty of the subjects. However, Wiesehöfer warns that one should not over-exaggerate the tolerant character of this ideology. There are two sides to this ideology: "On the one hand, the writings of the Achaemenid kings presuppose that subject loyalty is the norm, and they consider it a divine command and royal responsibility to provide justice, 'truth,' and well-being for all the inhabitants of the Empire. In turn, the well-being of the inhabitants is also desired by the gods, and Ahura Mazda qualifies the king specifically for these tasks. However, the inscriptions are very clear about the threat of sanctions that must be borne in mind by those who do not wish to follow divine and royal command... A stickand-carrot guarantee of well-being and graveyard silence after the suppression of rebellions were the two sides of the pax Achaemenidica at all times." ${ }^{\prime 15}$ Elsewhere ${ }^{16}$ Wiesehöfer indicates that this might also be an explanation for the fact that very peaceful scenes were depicted on the outer walls of the royal palace in Persepolis, but the inner walls of the palace, as well as some Persian glyptic art (or Kleinkunst) show battle scenes and scenes of subjugation.

Now, what was the position of the Jewish returnees from exile in this context? We know that the same Cyrus promulgated a decree in $538 \mathrm{BCE}$ (of which we have translated fragments available in Ezra 1 and $2 \mathrm{Chr} 36$ ) liberating the exiles to return to their land. It is even stated in this decree that they were given permission to rebuild their temple and restore their cult with the financial support of the empire. This decree prompted the first wave of returnees, which was later followed by more.

These events changed the status of Israel dramatically - even more than the Babylonian exile which started with the destruction of Jerusalem in 587 BCE. Whereas the selfunderstanding of the people of Israel was closely linked to the Davidic monarchy during the pre-exilic time, and whereas they dreamt about the resurrection of this Davidic monarchy during the exile, the post-exilic community had to face the reality of their becoming a subjugated province under Persian imperial rule - a province called Yehud. The sociopolitical, socio-cultural and socio-religious environment therefore changed dramatically. Their exilic expectations of liberation were surprisingly not fulfilled by a Davidic king, but rather by a Persian emperor who acknowledged their cultural and religious aspirations. No wonder that this was probably the most fruitful time of theological reflection in Israel's history, resulting in many of the biblical writings that are contained in the Old Testament.

Ibid, 89-90

14 See also Idem, "From Achaemenid Imperial Order to Sasanian Diplomacy: War, Peace, and Reconciliation in Pre-Islamic Iran," in War and Peace in the Ancient World (ed. KA Raaflaub; London: Blackwell, 2007), 124-127.

15 Idem, "The Achaemenid Empire in the Fourth Century BCE: A Period of Decline?" in Judah and the Judeans in the Fourth Century BCE (eds. O Lipschits, GN Knoppers and R Albertz; Winona Lake, ID: Eisenbrauns, 2007), 26.

16 Idem, 'War, Peace, and Reconciliation', 126. 
In order to come to a better understanding of the so-called tolerance in the Persian era, it could be a very useful exercise to look at how the subjugated nations engaged with this context. The text of the Cyrus Cylinder provides valuable material in this regard - but, it cannot be ruled out that Cyrus himself commissioned this inscription to the Babylonian Marduk priests, and that it therefore contains a very ideologically-biased portrayal from the centre of power. The biblical literature from this era may provide us with more useful material. We know that the province Yehud was nothing more than an insignificant outskirt of the Persian Empire. Those voices coming from this little corner can rightly be considered to represent the marginal voices under imperial existence - when seen from the perspective of the centre of socio-political power. It is not denied here that the biblical literature is also ideologically-biased in its views. However, the usefulness of investigating the biblical material lies in the fact that it represents a view on the Empire from the margins.

What follows is then an attempt to observe from the biblical writings what strategies of adaptation were practised in Yehud, and what that reflects of the conditions in the Persian Empire. I will first provide a more general overview, and then concentrate on one specific case study from the Books of Chronicles.

\section{How did the Post-Exilic Faith Community in Yehud Engage with the Imperial Context?}

\section{General overview}

In his identification of source materials for examining the history of the Persian period in Yehud, Lester Grabbe identifies the following biblical material as literature from this period: ${ }^{17}$

- Ezra-Nehemiah;

- Haggai, Zechariah and Malachi;

- Other prophetic writings (The Isaiah tradition, Joel, Jonah, Ezekiel);

- The Books of Chronicles;

- The Priestly Document;

- The Writings (Proverbs, Job, Esther, Ruth, Song of Songs).

It is of course impossible to discuss all these books in detail here. A small selection will, however, be discussed from a very narrow perspective, namely by asking the question what Jewish self-understanding is reflected in this literature, and how that interacted with the imperial context of the time. As indicated in the beginning of my contribution I take my theoretical point of departure in the idea of 'textual identities'. Texts are not mere reflections of well-defined identities, but are rather part of ongoing identity negotiation processes. This applies pertinently to texts originating in contexts of transition, such as the post-exilic period under Persian rule in Yehud.

We start with Ezra-Nehemia. This book tells of the return from exile and the rebuilding of the temple and walls of Jerusalem. It is reported in Ezra 3 that the foundation stones of the temple were re-laid under Sheshbassar. However, immediately thereafter, as reported in Ezra 4, the rebuilding met opposition from 'the opponents of Judah and Benjamin'. These 'opponents' which is probably a reference to the people living in the Samaritan province to the north of Yehud, received support from the Persian king Artaxerxes to stop the

17 See Grabbe, A History of the Jews and Judaism in the Second Temple Period. Volume 1. Yehud: A History of the Persian Province of Judah (London: T\&T Clark, 2004), 70-106. 
rebuilding of the temple in Jerusalem. These opponents urged the Persian king to look into the archival records to see for himself that the Jews in Judah and Benjamin actually had a long record of rebellion against the superpowers of the past. The Persian king then indeed finds records testifying to the rebellious past of Jerusalem, and the rebuilding is stopped until the second year of Darius. ${ }^{18}$ Only in the days of this later Persian emperor the Jews in Jerusalem received support from the Persian governor in the area west of the Euphrates. The governor, Tattenai, reminded the new Persian king that there were archival records available from the time of Cyrus in which the late king's commission to rebuild and restore the temple in Jerusalem was recorded. Darius finds these records, and the rebuilding could continue and the temple be completed.

The rebuilding of the walls again met opposition from the province to the north of Yehud, namely Samaria, as well as from some other leaders from provinces around Yehud (see Neh 4:7 where they are mentioned by name - Ammonites, Arabs and Ashdodites). Although the Persian context is still in the background here, there is no specific intervention from the side of the Persian emperor. The literature rather reflects the interprovincial rivalry in the Syro-Palestinian area. We learn from archaeological records that the area around Samaria was less affected by the exile, and that this Persian province was more affluent and powerful than Yehud in the days of restoration. ${ }^{19}$ This socio-economic and socio-political context probably forms the backdrop of this rivalry.

What is interesting of Ezra-Nehemiah, however, are the parts reflecting a specific selfunderstanding of the Jewish community in these days. In both Ezra 10 and Nehemiah 13 we find sections indicating that all foreign wives and children of mixed descent were chased out of Jerusalem. Nehemiah 13:23-25, as an example, indicates that there was no tolerance whatsoever in this regard:

23 In those days also I saw Jews who had married women of Ashdod, Ammon, and Moab; 24 and half of their children spoke the language of Ashdod, and they could not speak the language of Judah, but spoke the language of various peoples. 25 And I contended with them and cursed them and beat some of them and pulled out their hair; and I made them take an oath in the name of God, saying, "You shall not give your daughters to their sons, or take their daughters for your sons or for yourselves" (NRSV).

These "texts of terror ${ }^{20}$ reflect a strong exclusivist or particularistic understanding of the Jewish identity. The strong polemic in these texts is particularly directed against the neighbouring nations again.

The book of Esther can perhaps also be associated with this more exclusivist stance of EzraNehemiah. The book tells the story of how a Jewish girl became queen in the Persian court. But it also tells, from a Jewish perspective, how the existence of the Jews in the Persian Empire was threatened. Haman, a high official in the court of Ahasveros, is the antagonist in the narrative, while Mordechai, the foster parent of Queen Esther, is the Jewish protagonist. The latter succeeded to impress the Persian emperor Ahasveros, as well as to outwit Haman in his plan to eradicate all Jews from the empire. After Haman was exposed and killed on his own gallows, the Jews received permission to defend themselves against any opposition. Esther 9 then tells the story of how all Jewish enemies/opponents were killed:

18 The prophet Haggai's message is normally placed in the time when the building project was stopped.

19 See GN Knoppers, 'Revisiting the Samarian Question in the Persian Period,' in Judah and the Judeans in the Persian Period (eds. O Lipschits and M Oeming; Winona Lake, ID: Eisenbrauns, 2006), 265-289.

20 This term was coined by Phyllis Trible in her publication Texts of Terror: Literary-feminist Readings of Biblical Narratives (Philadelphia: Fortress, 1984). 
1 Now in the twelfth month, which is the month of Adar, on the thirteenth day, when the king's command and edict were about to be executed, on the very day when the enemies of the Jews hoped to gain power over them, but which had been changed to a day when the Jews would gain power over their foes, 2 the Jews gathered in their cities throughout all the provinces of King Ahasuerus to lay hands on those who had sought their ruin; and no one could withstand them, because the fear of them had fallen upon all peoples... 5 So the Jews struck down all their enemies with the sword, slaughtering, and destroying them, and did as they pleased to those who hated them. 6 In the citadel of Susa the Jews killed and destroyed five hundred people. 7 ... 12 The king said to Queen Esther, "In the citadel of Susa the Jews have killed five hundred people and also the ten sons of Haman. What have they done in the rest of the king's provinces? Now what is your petition? It shall be granted you. And what further is your request? It shall be fulfilled." 13 Esther said, "If it pleases the king, let the Jews who are in Susa be allowed tomorrow also to do according to this day's edict, and let the ten sons of Haman be hanged on the gallows." 14 So the king commanded this to be done; a decree was issued in Susa, and the ten sons of Haman were hanged. 15 The Jews who were in Susa gathered also on the fourteenth day of the month of Adar and they killed three hundred persons in Susa; but they did not touch the plunder. 16 Now the other Jews who were in the king's provinces also gathered to defend their lives, and gained relief from their enemies, and killed seventy-five thousand of those who hated them; but they laid no hands on the plunder. 17 This was on the thirteenth day of the month of Adar, and on the fourteenth day they rested and made that a day of feasting and gladness. 18 But the Jews who were in Susa gathered on the thirteenth day and on the fourteenth, and rested on the fifteenth day, making that a day of feasting and gladness. 19 Therefore the Jews of the villages, who live in the open towns, hold the fourteenth day of the month of Adar as a day for gladness and feasting, a holiday on which they send gifts of food to one another (NRSV).

This great escape of the Jews with Persian imperial support then leads - according to this narrative - to the institution of the Purim festival in which these events were commemorated. It is clear that this literature wanted to criticize any anti-Jewish sentiment in the empire, and wanted to claim support from the Persian emperor in this regard.

Another tone can be seen in the prophetic writing of Jonah that certainly supports a more inclusivist stance. It seems that this book represents a universalist perspective on the place of Gentiles in God's plan in which the point of view is reflected that non-Israelites may have access to the God of Israel. Grabbe remarks that "these indicate a tendency in some circles toward the universalism of worship and salvation." He continues: "This does not mean that Gentiles would be accepted just as they are because conversion to Yahwism is presupposed, but it goes against the narrow genealogical and exclusivist view in some circles... Gentiles can repent of their sins; God will listen to them in such cases; God is concerned about their welfare and not just Israel's." ${ }^{21}$ This is particularly pertinent in the closing verses of the book which ends with a rhetorical question of Yahweh:

10 Then the Lord said, "You are concerned about the bush, for which you did not labor and which you did not grow; it came into being in a night and perished in a night. 11 And should I not be concerned about Nineveh, that great city, in which there are more than a hundred and twenty thousand persons who do not know their right hand from their left, and also many animals?" (NRSV).

It is clearly a more inclusivist position that we find here which is much different from the perspectives of Ezra-Nehemiah and Esther.

21 Grabbe, History of the Jews, 96. 
This inclusivism is also reflected in the book of Ruth. A very prominent aspect of this narrative is that Ruth was a Moabite, but that she nevertheless opted to settle in Judah and to adopt the Yahwistic religion. In the end she becomes the wife of Boaz, a Judahite, and gives birth to a son who became an ancestor of King David. Grabbe remarks about this narrative: "In the Persian period when this was probably written, with the examples of trying to break up marriages with 'foreigners' in Ezra-Nehemiah, a reader could not escape the contrary message of Ruth: foreigners can become good Jews, foreign wives can be exemplary followers of divine law, and there is no reason to think that their offspring should be excluded from the community as polluted or illegitimate. ${ }^{22}$ It is clear that we hear another voice, another opinion here over against some of the more exclusivist voices that we have referred to above.

The inclusivist tendency is also reflected in other Old Testament literature from this period, such as in Deutero- and Trito-Isaiah, as well as in Malachi. However, the above examples suffice to show certain tendencies. Let us therefore move on in our discussion by focussing on one specific case study, namely the Books of Chronicles. After focussing on certain tendencies in the latter book, I will formulate some observations from the literature we have discussed above.

\section{Case Study: The Books of Chronicles}

I have indicated elsewhere that the macrostructure of the Books of Chronicles is quite significant for its interpretation. ${ }^{23}$ The reinterpretation of the history of Israel (particularly of the pre-exilic Kingdom of Judah) is situated in a universalistic context. The book starts off with nine chapters of genealogies, forming a grand exposition of where Israel fits into the family of nations. The genealogical description starts with Adam, indicating that the frame of reference for this history is not so much the particular community in Yehud, but rather the universal history of humankind.

This universalistic tone is echoed at the end of the book in 2 Chronicles 36:22-23 where the Persian king Cyrus is quoted:

22 In the first year of King Cyrus of Persia, in fulfillment of the word of the Lord spoken by Jeremiah, the Lord stirred up the spirit of King Cyrus of Persia so that he sent a herald throughout all his kingdom and also declared in a written edict: 23 "Thus says King Cyrus of Persia: The Lord, the God of heaven, has given me all the kingdoms of the earth, and he has charged me to build him a house at Jerusalem, which is in Judah. Whoever is among you of all his people, may the Lord his God be with him! Let him go up" (NRSV).

This final section portrays the Persian emperor in a very interesting context: Firstly, Cyrus is portrayed here in a prophet-like manner. Cyrus's proclamation is introduced with the typical Yahwistic prophetic formula in adapted form, namely "Thus says King Cyrus of Persia..." Secondly, the close connection between Yahweh, the God of Israel, and the foreign king of Persia is emphasized here. It is Yahweh who 'stirs up his spirit', but it is also claimed that Yahweh, the God of heaven, gave all the kingdoms of the earth to Cyrus, and that He commissioned him to let the temple in Jerusalem be rebuilt. And thirdly, all this is seen as a fulfilment of the prophecy of Jeremiah, a well-known prophet of the Yahwistic tradition. This positive portrayal of Cyrus and his linking with the Yahwistic faith is

22 Ibid, 312.

23 See e.g. LC Jonker, 'The rhetorics of finding a new identity in a multi-cultural and multi-religious society,' Verbum et Ecclesia 24/2 (2003), 396-416. 
significant. It reminds us of the description of Cyrus that we observed in the Cyrus Cylinder, namely that the actions of this Persian king are described within the religious framework of the subjugated nation. The portrayal in 2 Chronicles 36 probably reflects the amount of freedom that was experienced and claimed in the outskirt province of Yehud to put the Persian rulers in their own religious and theological framework. But it probably also reflects a slight polemic in the direction of the Persian rulers that Yahweh is actually in charge of this world - not only in the imperial periphery, but also in the centre of imperial power.

I have indicated in other publications ${ }^{24}$ that one should be sensitive to the fact that Chronicles communicates on different levels. On the one hand (and this is the understanding emphasized by the majority of Chronicles scholars), the Book of Chronicles represents a powerful identity formation discourse within Jerusalem and the province of Yehud. It therefore speaks 'inwards', towards the Jewish returnees who were in a process of restoration after the exile. This inward discourse emphasizes that the new socio-political dispensation under Persian imperial rule should be accepted as coming from Yahweh, their God.

This same communication, on the other hand, also communicates 'outwards', that is, towards the Persian leadership - whether it was the Persian rulers or (more probably) the Persian governors in Jerusalem, Samaria and elsewhere. It emphasizes that 'All Israel' is given a place among the nations by Yahweh, the God of heaven (as He is called in $2 \mathrm{Chr}$ 36). It also emphasizes with all the royal narratives taken over and adapted from the earlier historical traditions (particularly the Deuteronomistic History, but also from the Pentateuch) that Yahweh, their God, calls for obedience to Him and proper observation of Yahwistic worship (the Passover, in particular). One may conclude from this that the Chronicler had a very positive stance over-against the Persian imperial rule, although the uniqueness of the Yahwistic faith was still emphasized.

The portrayal of other neighbouring nations is, however, ambiguous in Chronicles. Although the genealogies in chapters 1-9 include the neighbouring nations, such as the Ammonites, Moabites and Edomites in the family of Jacob (or rather, Israel, as he is constantly referred to by the Chronicler), the royal narratives in 2 Chronicles 10-36 often emphasize opposition to these nations. These chapters that narrate the royal stories of the kings of Judah often include battle accounts in which these smaller nations feature. Almost all these accounts belong to the Chronicler's own material. One representative example is the battle of Jehoshaphat against the peoples from the East ( $2 \mathrm{Chr} 20)$ :

1 After this the Moabites and Ammonites, and with them some of the Meunites, came against Jehoshaphat for battle. 2 Messengers came and told Jehoshaphat, "A great multitude is coming against you from Edom, from beyond the sea; already they are at Hazazon-tamar" (that is, En-gedi). 3 Jehoshaphat was afraid; he set himself to seek the Lord, and proclaimed a fast throughout all Judah. 4 Judah assembled to seek help from the Lord; from all the towns of Judah they came to seek the Lord. 5 Jehoshaphat stood in the assembly of Judah and Jerusalem, in the house of the Lord, before the new court, 6 and said, "O Lord, God of our ancestors, are you not God in heaven? Do you not rule over all the kingdoms of the nations? In your hand are power and might, so that no one is able to withstand you. 7 Did you not, O our God, drive out the inhabitants of this land before your people Israel, and give it forever to the descendants of your friend Abraham? 8 They have lived in it, and in it have built you a sanctuary for your name, saying, 9 'If

24 See e.g. Idem, 'The Cushites in the Chronicler's version of Asa's Reign: A Secondary Audience in Chronicles?', Old Testament Essays 19/3 (2006), 863-881 where I have argued this point. 
disaster comes upon us, the sword, judgment, or pestilence, or famine, we will stand before this house, and before you, for your name is in this house, and cry to you in our distress, and you will hear and save.' 10 See now, the people of Ammon, Moab, and Mount Seir, whom you would not let Israel invade when they came from the land of Egypt, and whom they avoided and did not destroy - 11 they reward us by coming to drive us out of your possession that you have given us to inherit. $12 \mathrm{O}$ our God, will you not execute judgment upon them? For we are powerless against this great multitude that is coming against us. We do not know what to do, but our eyes are on you." 13 Meanwhile all Judah stood before the Lord, with their little ones, their wives, and their children. 14 Then the spirit of the Lord came upon Jahaziel son of Zechariah, son of Benaiah, son of Jeiel, son of Mattaniah, a Levite of the sons of Asaph, in the middle of the assembly. 15 He said, "Listen, all Judah and inhabitants of Jerusalem, and King Jehoshaphat: Thus says the Lord to you: 'Do not fear or be dismayed at this great multitude; for the battle is not yours but God's. 16 Tomorrow go down against them; they will come up by the ascent of Ziz; you will find them at the end of the valley, before the wilderness of Jeruel. 17 This battle is not for you to fight; take your position, stand still, and see the victory of the Lord on your behalf, O Judah and Jerusalem.' Do not fear or be dismayed; tomorrow go out against them, and the Lord will be with you" (NRSV).

What is seen in this narrative, which is also typical in other battle accounts in Chronicles, is that reliance on Yahweh leads to victory over the nations around Judah. It therefore seems that the Chronicler's view was that - although these other neighbouring nations were genealogically related to Israel - they did not belong to the religious community that sought Yahweh. This drawing of boundaries reveals that in the Persian era there was still not a general acceptance of the other provinces and their inhabitants, although one cannot detect such a strong exclusivist ideology here like in Ezra-Nehemiah or Esther.

\section{Summary}

Let me now try to summarize our observations on the biblical texts from the Persian era in two points:

- Firstly, when reading these texts, we become aware of the fact that there were different, even opposing, voices in Yehud on the inclusion of foreign nations in their self-understanding as the people of Yahweh. Some writings (such as Ezra-Nehemiah, Esther, and to a lesser extent also Chronicles) polemicized strongly against the inclusion of foreigners in the definition of the post-exilic community. Others (such as Jonah, Ruth and the genealogies of Chronicles) take an opposite stance. They deliberately include other nations in their understanding, be that the neighbouring nations such as the Moabites, or by means of an anachronistic reference to the Assyrian Empire in Jonah.

- Secondly, it is interesting that nowhere do we encounter an explicitly negative polemic against the Persian rulers. Even Ezra-Nehemiah and Esther do not portray the Persian emperors negatively. There are other antagonists, such as Sanballat of Samaria in Nehemiah or Haman in Esther who try to manipulate the Persian kings. However, together with particularly the Books of Chronicles, the other literature from the time never condemns the Persian rulers. This may be understandable from the imperial context where minority voices would not dare to come out too loudly against the Persian rule. However, it could also be an indication that the Persian rule as such was not considered evil. 


\section{Identity Negotiation and Human Dignity: Some Observations}

This last point brings our discussion back to where we started: How should we evaluate the conditions in the Persian era? The following observations will try to answer this question:

- From the biblical literature that we studied, and particularly from the mainly positive portrayal of the Persian emperors in that literature, we may perhaps conclude that there was a greater extent of tolerance in the Persian Empire compared to its predecessors. Persian historiographers warn us, however, not to over-interpret this tolerance, and not to confuse it with modern-day discourses on human dignity and human rights. This greater tolerance may have been pragmatic (as some scholars would say): it may just have been cheaper to run an empire without revolts every now and then in all the outlying provinces. This tolerance would also not exclude harsh measures from the side of the imperial power centre to kerb opposition or disloyalty. However, it seems that the socio-political landscape under Persian rule was much friendlier than the Babylonian or Assyrian predecessors. The Persian dispensation allowed for a diversity of nations with diverse languages and religions to prosper. The Jewish returnees from exile also benefitted from this dispensation.

- As a spin-off of this greater extent of tolerance in the Persian Empire, subjugated nations could take the freedom and courage to negotiate an own identity. These processes of identity negotiation, such as those we witness in the biblical writings from the time, took place in (dis)continuity particularly with the provincial neighbours, and not so much with the imperial centre of power. However, this does not mean that there were not subtle polemical discourses in the direction of the Persian leadership. These discourses often had a religious-theological theme (as we may expect from the witnesses contained in the biblical writings). The tolerance of the Empire, and particularly the Persian emperor's strategy of adopting the religious parlance of the local contexts, gave the community in Yehud the courage to argue that obedience to Yahweh, the God of Israel, leads to true peace, rest and order.

- The situation under Persian rule naturally also fostered what is called hybrid or overlapping identities in postcolonial theory. The Books of Chronicles are probably the best example to illustrate this tendency. There is no doubt that the Chronicler wanted to facilitate loyalty towards the imperial centre. However, simultaneously and not in contradiction, a local identity of 'All Israel' is negotiated by this literature. This is done by means of an interesting process of engaging with traditions of the past - in continuity, but also in discontinuity with these traditions.

- The culture of tolerance we may presuppose in the Persian Empire did not prevent strong opposition to develop. The books Ezra-Nehemiah and Esther are probably the best examples reflecting this point. In some parts of the community in Yehud there were voices arguing for a very narrow, particularistic and exclusivist understanding of the Jewish identity. However, this trend seems to be directed mainly against the neighbouring nations, although the book of Esther may also be interpreted as an anti-Persian polemic.

- Related to the abovementioned - and this could be the most disappointing aspect of our observations - we may state that the culture of tolerance did not prevent serious abuses to happen. Whether ethnic cleansing practices as reflected in Ezra-Nehemiah did in fact happen, we will never know. However, the discourses on the sad exclusion of women and children of foreign descent from the definition of who a true Israelite was, remain disappointing. It is even disturbing to acknowledge that the greater tolerance under 
Persian rule did not prevent texts such as these being canonized in the Jewish (and Christian) traditions!

- The above observations lead us to a more general conclusion from our study: There is a delicate relationship between identity negotiation processes and a culture of tolerance (in which human dignity is respected). It seems that discourses on human dignity in our own day should not assume that processes of identity negotiation among diverse groups in society will necessarily support a positive movement in society. In some circumstances, the more tolerant tone of human dignity discourses may open up the opportunity for strong exclusivist tendencies to develop in parts of society. 